\title{
Citizen Journalism in France: Professional Practice and Self-Regulation
}

\author{
By Waleed Ali
}

\begin{abstract}
In a few years, the media landscape has undergone rapid and unprecedented transformations, due to the significant advancement of Information and Communication Technologies (ICTs), which have greatly influenced the publication and the press. In this context, citizen journalism appeared in the wake of Web 2.0 that gives individuals the opportunity to produce and distribute their own content, as well as allowing them to interact with each other. However, the increasing dependence on citizen journalism at an unprecedented form also highlights the importance of studying this phenomenon in depth. This study aims to identify citizen journalism in France-especially about its implications for journalistic practices, as well as the selfregulation of this phenomenon. The study concludes that, this form of journalism is not professional journalism because they do not have the same objectives. Besides, citizen journalists are not "sources" of information but that they are new filters to the news. Thus, citizen journalism does not pose a threat to professional journalism. However, its collaboration with traditional journalism is a benefit, because it alone is not credible. The study found also that self-regulation would be the real benefit or a compromise to keep the relation between professional and non-professional journalism.
\end{abstract}

Keywords: citizen journalism, practice, self-regulation, user-generated content.

\section{Introduction}

In a few years, the media landscape has undergone rapid and unprecedented transformations, due to the significant advancement of Information and Communication Technologies (ICTs). These have greatly influenced the publication and the press. In this context, the social web appeared in the wake of Web 2.0, "a sociotechnical device characterized by its interactive platforms and new collaborative practices". This new generation of Internet applications and services supports of so-called participatory dimension, which gives individuals the opportunity to produce and distribute their own content, as well as allowing them to interact with each other. Thanks to the Web 2.0 platforms, anyone can now produce and distribute journalistic content; this is called user-generated content.

Thus, this privilege no longer belongs to the information professionals alone. This phenomenon obviously affected journalism, whose practice suddenly seemed to open up to the greatest number. Authors have even claimed that "every citizen is a potential journalist" (Rebillard, 2007, p. 16) and that "everyone capable of producing news" (Gillmor, 2004). These amateur information initiatives that have taken off with the emergence of the Internet are described as citizen journalism, participatory journalism or citizen reporter.

There is no doubt that we are living in the realm of new media or the "fifth estate" (Newman 2012, p. 15), which has enabled people to raise their voice on

${ }^{*}$ Lecturer, Department of Media, Tanta University, Egypt \& Scientific Researcher, ENSSIB de Lyon, France. 
what they feel needs attention. These people are, thus, termed as citizen journalists (Rabia, 2017, p. 55). Since 2005, France has been experiencing new forms of online journalism, described as "participative", that is to say offering nonjournalists internet users the opportunity to participate in the development of information, in various forms. The AgoraVox site was launched in 2005. The starting point of the founders is to consider that, thanks to the effective democratization of multimedia and ICTs, "every citizen can potentially become a "reporter" capable of identifying and proposing high value-added information". AgoraVox's editorial policy is "to make freely available to its readers, thematic information as far as possible, unpublished, and detected by the citizens".

Indeed, the issue of citizen journalism has been the subject of several kinds of research, particularly in France, which have made it possible to trace the contours of this object, to better understand the stakes it raises and to identify the main issues. Citizen journalism is an important topic for investigation today because of the difficult times that many newspapers are facing, which may be one of the things that lead newspapers to their survival in tough economic times (Fico et al., 2013). Citizen journalism can also serve as a potential way to "revitalize public debate" (Larsson, 2014, p. 78) in a time of loss of the credibility and objectivity of traditional media (Carr, Barnidge, Byung, and Tsang, 2014).

Citizen journalism is a soft paradigm that spreads like wildfire among active Internet users. The weakening of the traditional boundaries between sources, media and the public reactivates the imaginary of a disintermediated communication (Olivier, 2007), where editorial contents circulate outside the traditional media circuits. Also known as basic journalism, network journalism, participatory journalism, hyper-local journalism, bottom-up journalism, distributed journalism.

Based on the discussion above, we can say that citizen journalism is a concept based on the active participation of readers, viewers, and listeners in the process of collecting, selecting, analyzing and disseminating news and information. However, citizen journalism through its existence raises issues related to its practice and role in society and the impact it might have on traditional journalism besides the issues of self-regulation

\section{Literature Review}

In this section, we will work to build our theoretical framework that is to conceptualize our problematic by defining the main concepts used in this research and arranging them.

\section{Citizen Journalism: From Public to Individualism}

Definition of citizen journalism. The emergence of a new generation of websites underpinning a bottom-up innovation dynamic (Cardon \& DelaunayTeterel, 2006) has helped to found new areas of communication, information, and journalism. New editorial and sociotechnical practices then appeared, like the one 
that will study here: citizen journalism. In the past years, journalists and researchers have defined citizen journalism countless times. Deuze described participatory journalism as "any kind of new work at the hands of professionals and amateurs, of journalists and citizens" (Deuze, Bruns, and Neuberger, 2007, p. 323). More recently, readers of newspapers were given the opportunity to write and publish their own original material as citizen journalists through letters to the editor (Allan, 2007). As technology has advanced, so have the ways that citizen journalists can make contributions via the web (Braun \& Gillespie, 2011). Now, a citizen journalist can be someone who contributes content to blogs, takes photos and shares them online (Goode, 2009).

Indeed, we found that authors and researchers used many names to talk about the practices inherent to "amateur participation in news sites, understood as the production, by "non-journalists" of content related to the news" (Pignard \& Noblet, 2009, p. 1). In addition to the term citizen journalism, others are used in both French and English, such as participatory journalism, amateur journalism, ordinary journalism, citizen-reporter, citizen journalism, participatory or participative journalism, people's journalism, citizen reporter, etc. However, several authors use different appellations without distinction, without favoring one

The expression citizen journalism, while widely used, seems to be primarily assumed by leading essayists who have defended the subject, such as De Rosnay in France (2006) and Gillmor in the United States (2004). Although some researchers consider it objectionable, including Ruellan who believes that this "suitcase" "assigns a very heavy role for the media or individuals - why these and not others - monopolize" (Ruellan, 2007, p. 3). From this perspective, Rebillard defines what he calls participatory journalism as "the intervention of nonprofessionals in journalism in the production and dissemination of current news on the Internet" (Rebillard, 2008, p. 354). This definition is similar to Ruellan's (2007):

"Netizens, non-professionals in journalism, contributes directly to the production of news. They search for data, analyze it and put it online, with or without the help of professionals". (p. 2)

Radsch (2013) defines the essence of citizen journalism as "an alternative and activist form of newsgathering and reporting that functions outside the mainstream media institutions often as the repose to the shortcoming in the professional journalistic field". One can, of course, wonder if these "non-professionals of the journalism" really adopt a journalistic approach which makes them contribute "directly to the production of the new information". In his book on the social history of digital technologies, Mondoux prefers to use the term citizen-reporter and describes the phenomenon by giving citizens a more modest role. Thus, since 2003-2004, the notion of citizen-reporter is gradually being imposed, that is to say, those individuals freed from the institutional media (the fourth power) and "free" to report the "real" facts as witnesses direct. The public is invited to submit their comments, images, and video clips and thus become part of traditional journalistic production (Mondoux, 2011, p. 189). 
Mark Glaser ${ }^{1}$ thinks that "citizen journalism allows people without journalism training to use contemporary communication tools and Internet broadcasting capabilities to create, improve or verify information". According to Jay Rosen, citizen journalists are "the people who made up the old audience", who was at the end of a one-way media chain. Today we are no longer in this situation; the old audience has simply become more real, more capable and less predictable. Joel de Rosnay and Carlo de Revelli define the citizen journalism or "participative" as a concept present on spaces of diffusion which publish and centralize information coming from individuals, sorts of testimony inform articles, pictures, or videos. This concept is not part of the criticism of the media or the information they transmit. It is characterized by "a notion of responsibility and inscription in the life of the city, without a predefined or imposed political orientation".

According to Richard Patrosso ${ }^{2}$, citizen journalism is a fifth power that must control the work of professional journalism to denounce corruptions and restore the truth if it contains errors. It is a voluntary act that does not have the same obligations as a professional journalist. Neutrality is not required since the citizen journalist has to denounce. In addition, he must seek the maximum visibility and therefore get out of the territory of his blog to be part of a citizen newspaper with a large audience.

Typology of citizen journalism. Lasica (2003) classified citizen journalism into the following categories: 1) Participation of the readers (such as comments on a site, a blog; photos or videos captured during an event; or local news written by a member of a community), 2) Independent news and information Websites (for example, "consumer reports" in the United States or "60 million consumers" in France, 3) Participatory news sites (like OhmyNews in Korea or AgoraVox in France, which citizen-reporters contribute a significant amount of material), 4) Collaborative media based on contributors (such as Slashdot in America and Rue89 in France), 5) Personal broadcast sites (podcasts, web radio), and 6) Other kinds of "thin media" (mailing lists, email newsletters).

Cheynel and Noblet (2009) provide a good classification of the different types of sites hosting amateur participation in the journalistic field. We present a summary of these sites below.

1) Sites out of journalistic-media field. First sites to have systematically and regularly appealed to amateur contributions. Common point: not being worn by mainstream media companies. They also include video news exchange platforms such as Citizen News launched by YouTube.

2) Sites belonging to the media-journalism field. Amateur participation appears as a complement to content produced by professionals. We find in this category the sites:

- Traditional media sites that use amateur contributions, whether in the form of chats, jokes, comments, sending photos/videos, etc.

\footnotetext{
${ }^{1}$ Journalist specialized in Internet and new communication technologies issues. He writes for the Los Angeles Times, CNET, HotWired, The New York Times.

${ }^{2}$ Philosopher and editor in agoravox.com
} 
- Sites of pure players (sites that are exclusively found on the net, whose main positioning is based on a co-presence of content produced by journalists and amateurs); as "Rue89".

- Sites launched by media groups but demarcated from the main title (intermediate form), as is the case for Le Monde.

AgoraVox: The first European initiative of citizen journalism. AgoraVox is defined as "the first European initiative of citizen journalism". This site was created by Joël de Rosnay and Carlo de Revelli in 2005. The aim is to allow all information sensors to express themselves freely. According to the creators, as it is easily possible to be the witness of an event (thanks to the digital cameras and the camcorders), it must be as simple to be able to diffuse the information which results from it. That is why AgoraVox is completely free for writers. The site is based on "grassroots journalism": the idea that news does not come exclusively from the top (the media) but also from readers. Thus, this site has a motto that says "Every citizen is a Reporter".

Figure 1. Screen Shot of AgoraVox Website

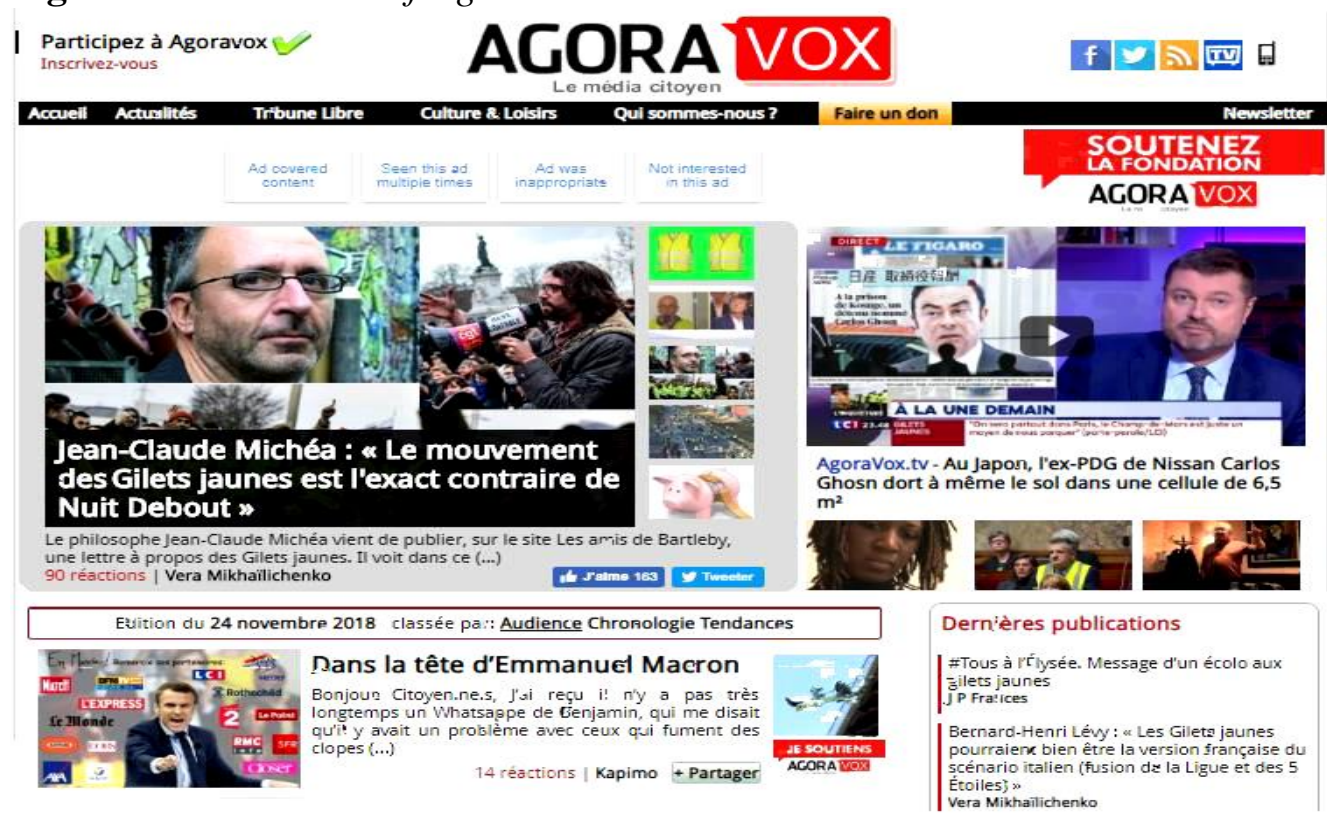

Source: https://www.agoravox.fr/.

AgoraVox wants to be the platform of the information but corresponds more to a collaborative blog where each editor delivers its analysis of events often followed in the professional press. Reading the site, it brings new insights into facts and events. It makes possible to leave the discourse of traditional journalism by taking problems from different angles. The site also allows opening the debate through the use of comments. Unfortunately, the large attendance of the site makes very quickly the follow-up comments. There is also a filtering of articles by Internet users themselves who can vote for or against an article based on his interest. This system does not make it possible to put in one article according to 
the number of votes (in the manner of Digg) but gives only an indication to the readers of the quality of the article (Figure 1).

In conclusion, AgoraVox looks more like a collaborative blog. Its main missions are information to the public and support for freedom of expression. Finally, it is also interesting to see how all the other growth indicators (number of articles published, editors, commentaries posted and moderators) have constantly progressed almost doubling all between 2009 and 2017 (Table 1).

Table 1. Growth Indicators between 2009 and 2017

\begin{tabular}{|l|c|c|}
\hline & December 2009 & October 2017 \\
\hline Published Article & 60.000 & 113.988 \\
\hline Editors & 50.000 & 90.467 \\
\hline Comments posted & 1.300 .000 & 3.319 .421 \\
\hline Moderators & 1.500 & 3.262 \\
\hline
\end{tabular}

Source: https://www.agoravox.fr/.

\section{Journalistic Practice in the Digital Age}

This study tries to look at the practice of Citizen Journalism, thus, it is important to understand how it has been practiced. It is also important to review the literature on citizen journalism around the globe, and citizen journalism in France. This is reviewed below. Our review of the literature has shown us that there are many scientific articles on the changes made by the Internet on journalistic practices. Since the end of the 1990s, many studies have focused in particular on the implications of ICTs for the journalistic profession. Le Cam and Estienne studied the practices of these "new information workers online", and also how they represent themselves and how their emergence weakens the boundaries between professionals and amateurs (Le Cam, 2006, Estienne, 2007). In this context, some researchers have analyzed the major issues raised by citizen journalism for the journalistic profession (Tredan 2007). The subject of information blogs is also widely discussed in the literature, whether it is to establish their portrait and the questions they raise in relation to journalistic identity (Le Cam, 2006) or to postpone in question the democratic potentialities often attributed to them (Pledel, 2006). Some researchers also sought to explain the social origins of citizen journalism by linking it to a crisis in the media (Tredan, 2007) and placing it in the continuity of public journalism (Le Cam, 2006; Ruellan, 2007; Tetu, 2008). Other researchers focused on contributors to determine who they were, and what their skills and motivations were (Aubert 2011; Tredan 2007).

It should also be noted that several sites exclusively dedicated to citizen journalism have been the subject of a detailed study, notably OhMyNews, AgoraVox and Rue 89 etc. (Aubert, 2011). Some researchers have concluded that the quality of amateur contributions often leaves something to be desired. They also noted that certain sites that host these practices, traditional media or pure players; we are now focusing more on professional supervision of citizens (Pignard \& Noblet 2008; Aubert 2011). 


\section{Objectives}

In the age of social networks, public participation seems to be a real golden age on the Internet. By making the participatory dimension possible, Web 2.0 technologies have given rise to amateur information initiatives, better known as citizen journalism. Indeed, the citizen journalism topic is important, especially in the area of democratic communities, because of the changing ways that news and information are shared within these communities.

This research aims to identify this phenomenon, its role in society, and its implications for journalistic practices, as well as the upheavals caused by what is called the "digital revolution".

\section{Methodology}

The increasing dependence on citizen journalism at an unprecedented form also highlights the importance of studying this phenomenon. Consequently, our study presents a practical support, by abandoning traditional methods and adopts new methods. In this respect, this study based on a systematic review of the literature, that differs from a narrative review. While a narrative review provides an overview of the content available on a given topic, a systematic review is more narrowly focused and seeks to assemble, critically appraise or evaluate and synthesize the results of primary studies in an integrative approach.

\section{Findings}

\section{Axes of Citizen Journalism Practices}

The practices of citizen journalism can be summarized in three main axes: (1) in its relations with traditional media/journalism, 2) its information and communication technologies (ICTs), 3) and the democratic society. Besides, we will also focus on the benefits that citizen journalism offer in relation to each of these axes.

\section{Axis of Media/traditional Journalism}

The crisis of public confidence. Of course, technological changes are not the only ones that have had an impact on the evolution of journalism. The social context also plays a determining role. According to several researchers and observers, the so-called traditional media and journalism are currently going through what appears to be a crisis of public trust. After having experienced in many countries a "good times" in the 1970s and 1980s, journalism seems to have plunged since the beginning of the 1990s into a period of questioning because of important socio-political and economic changes (Neveu, 2009, p. 93). 
Although the emergence of Web 2.0 is not the starting point for this role that media consumers are actively demanding, the potential of the tool has nevertheless accompanied this phenomenon of appropriation, which is reflected in the emergence of the term "Citizen journalism" claimed by many Internet users (Aubert, 2011, p. 99). Aubert believes that "journalism and its social function have been put to the test for some years by the evolution of the relationship with the information of the users" (p. 99). Tredan shares this conviction that citizen journalism is born as much from this moral crisis of the media as from the possibilities offered by the Internet.

"'Citizen Journalism' is part of the particular context of the rise of self-publication and the perception of a moral crisis in the mass media. The imagination of the Internet (Flichy, 2001) has produced tools aimed at democratizing the publication and distribution of information". (Tredan, 2007, p. 117)

Advantages of citizen journalism. Citizen media is presented as an interesting alternative to traditional media. Such a conception is based on the belief that the citizen media would have at least three advantages over traditional media, namely:

- Bridging the information gap. Citizen Journalism sites claim that the information provided by citizens is considered valid and worth publishing. They fill an information gap because the traditional media cannot cover everything, whether out of disinterest (especially for local news) or simply because they cannot afford it.

- Independence (less bias and censorship). The citizen journalism sites claim that offer information that differs from that offered by traditional media. Their emphasis on this point obviously reflects their perception that they are currently experiencing a crisis of confidence as they are suspected of being increasingly subject to the dominant powers, be they political or economic. In this context, they insist that they are more independent, freer and that the information they offer is unbiased. They believe that the editorial staff of the traditional media does not hesitate to censor the comments of journalists, which is not the case in the model of citizen journalism.

- Flexibility. Some sites such as AgoraVox also highlight the fact that the model of citizen journalism is more flexible, that it does not include the characteristic filters of larger organizations and that it, therefore, presents fewer constraints for the citizen reporter. In addition, the fact that more people have the opportunity to broadcast news allows sites to potentially have greater access to different contributor skills. It is implied that citizens are often better informed or have more expertise than journalists in certain fields.

Axis of information and communication technologies (ICTs). In this axis, we highlight the advantages that Information and Communication Technologies 
(ICTs) bring to citizen journalism, which gives it an advantage over traditional media/journalism.

New media model. With technological advances and the advent of so-called Web 2.0 or Social Web, which creates a real mass phenomenon (Mondoux, 2011, p. 172), the phenomenon of citizen journalism grows, while individuals have the opportunity to interact with others, produce and distribute content. In this form of journalism, the message can be edited stored and reproduced by anyone at any time, making the position of the receiving person more active and involved. Bowman and Willis (2003) describe citizen journalism as a bottom-up phenomenon in which there is little or no editorial oversight as shown in Figure 2.

Figure 2. Traditional Media vs. Participatory Media

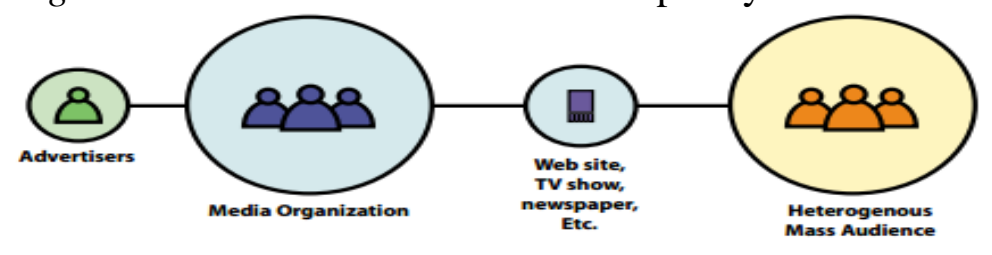

Traditional Media Model : Top-down news

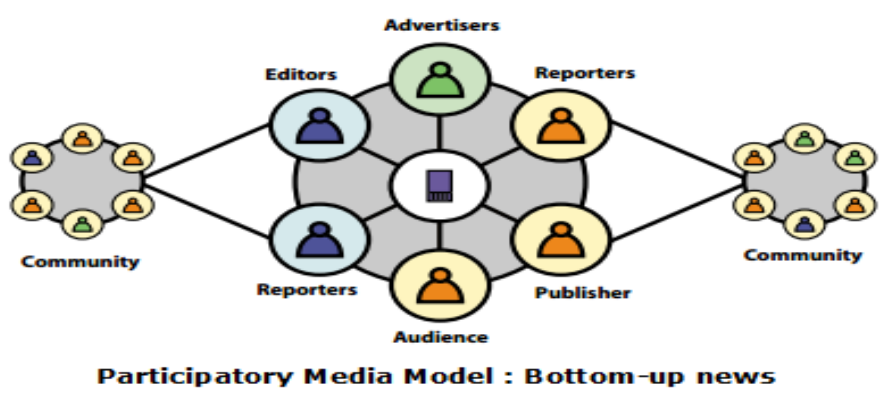

Source: Bowman and Willis (2003).

"While traditional news media have delivered information through a topdown, centralized model with journalists functioning as gatekeepers of information, online news media present greater opportunities for control and ownership as users assume more active roles in their news consumption experiences". (Deborah, 2008, p. 659)

The advent of new technologies is an integral part of media development. The history of communications has been shaped by the arrival of multiple technical inventions designed to enable, facilitate, extend, and even accelerate the spread of messages between individuals. Citizens now had a plurality of media that allowed them to confront the information that was offered to them "(Nobre-Correia, 2006, p. 16). By offering the opportunity to process information in real time, these technologies have led the journalist to change his practices and ways of doing things in order to deal with these new technical modalities.

In the field of journalism, the impact of the arrival of the Internet is multiple: for example, the influence of the Internet on the practices of traditional journalists and the emergence of "information workers online" (Estienne, 2007, p. 109), be it the journalists who feed the news sites of the dailies or the media present online or 
the citizens who launch their own blogs, professional journalists or amateurs wishing to express their opinion and to make their voice heard. As for the work of the journalist, he will have to adapt to the rapid pace of the production of the continuous information characteristic of the Web and be able to deploy simultaneously on different platforms.

\section{Advantages of Citizen Journalism}

- Network interconnection and strength of collaboration. The rise of Information and Communication Technologies (ICTs) has made it possible to connect people in a network. Collaboration made possible by technologies is seen as an advantage, if not a real strength, that can counteract traditional media, which is good for the democratic society. This phenomenon is described as a process of collective intelligence. The words power or power is also often used when referring to the power of the gathering of citizens.

- The speed of diffusion. Interconnected network members and increased access to technology allow citizen journalism sites to benefit from the presence of their members in the field. By giving citizens the opportunity to easily disseminate content, ICTs (Internet and mobile phones) allow them to report on the events they witness on the ground (in short, the "real"). This is seen as a definite advantage as more news can be reported to them from around the world. They invite users to fulfill this role of witness. This idea goes hand in hand with the rapidity of the diffusion that Information and Communication Technologies allow.

Axis of the democratic society. Citizen journalism is allowing increased participation of citizens in public debate. From this perspective, we discuss the relations between this new form of journalism and democratic society. First, we stress the democratic potential of ICTs and then discuss the benefits of citizen journalism for the democratic society.

Democratic potential of ICTs. Citizen journalism sites are more inclined to discuss the democratic potential of ICTs, the speech of AgoraVox, goes in this direction as well. The rise of the Internet is seen as a tool that gives real power to the citizen and allows them to better exercise this role in society.

\section{Advantages of Citizen Journalism}

- The platform of expression. Indeed, citizen journalism helps the public to express their opinion and to tell their story as they have lived. The huge number of blogs, Twitter accounts, Facebook and YouTube that flourish daily on the Internet serve as an example for this claim. With this type of journalism, one can notice that there is a variety of sources of information, such as bloggers, eyewitnesses and members of the public to write articles about their stories, they are also given the 
opportunity to speak for themselves and to give an alternative version of the facts, a version often different from that of the so-called international media and sometimes of those of the governments. The citizen journalism site (AgoraVox) is a platform where any citizen can express himself and make his voice heard. This is seen as a major advantage for the democratic society, with the understanding that if more people speak, democracy will be better. The citizen can make a difference; some even feel it is his duty to speak out.

- The multiplicity of points of view. By offering people the opportunity to speak, citizen journalism offers the democratic society a certain advantage because of the multiplicity of points of view that emanate from it. The diversity of voices and opinions is seen as a vital element of democracy, and a better understanding of the world.

- Educate and inform the people. The phenomenon of citizen journalism is present in the lives of citizens as a means of education and information. For example, citizen journalism has played an important role in educating and informing the population and the outside world of the so-called Arab Spring events, where foreign media have been banned from covering events. Indeed, users of blogs, Twitter, Facebook, YouTube, and other social networks have been elements of information leakage for an Arab world as tightly closed as during its political upheavals and disturbances and mass demonstrations. Members of the public, via the Internet, organized rallies and mobilized resources that led to the fall of political figures including Presidents Hosni Mubarak, Mohammed Morsi of Egypt and Colonel Muammar Gaddafi of Libya. Through these examples, citizen journalism has shown its need to be, its relevance in today's society and the important role it plays in informing and educating the population.

\section{Responsibility: The Missing Link in Citizen Journalism}

In the context of changing media landscape due to the significant advancement of ICTs, the issue of the practice of journalism recently has become the focus of considerable interest and attention. Newly, the practice of journalism had moved from professional to the citizen, where content can be published without passing through a single journalistic filter where assessments can be made about creditability, context, relevance (Fielder, 2009, p. 216). In this context, Ward (2011) defined change in journalism practice as the switch from the professional approach of "filter, and then publish", to the "publish, and then filter" even if this means "uncertainty about its source or accuracy" (Ward, 2011, p. 213).

Indeed, due to the lack of responsibility of digital media reporters, these tools can lead to exacerbating acts of violence, or purposefully used to threaten or terrorize particularly in countries where democratic processes are limited. For example, in 2014, members of the Islamic State purposefully filmed scripted footage depicting the beheading of captives. From this perspective, the lack of responsibility is the predominant issue or the missing link in the practice of citizen 
journalism. Steven Ward notes, that the method of citizen journalism is formed of "a participatory model of democracy which is libertarian in spirit" that cannot compete in effectiveness with professional journalism that is based on "objective news reporting and well-informed analysis" (Ward, 2011, p. 214). Journalism accountability can be secured only by "laws and regulations, markets, public, or professionals" (Ananny \& Kreiss, 2011, p. 324), and citizen journalism cannot be effectively monitored by any of these processes. This is due to the nature of the open online environment that allows anyone to publish any content at any time, besides individual anonymity.

In sum, citizen journalism cannot be effectively monitored by laws and regulations. This is due to the anonymity, as well as an "open environment" that allows anyone to publish any content "might be inaccurate" any time, in order to mislead news consumers.

\section{Regulation of Citizen Journalism}

The digital age has led many researchers to requisition the profession of journalist and its organization, even to consider "rethinking" because of its "structural transformations" (Peters \& Broersma, 2013). In this context, there are many studies announced the complete transformation of news media and/or journalism and even the death of the paid press in favor of renewed information, online, free and participative.

Regulation of newsrooms. Jane Singer studied journalism in terms of challenges to the notion of journalistic professionalism (Singer, 2003), or "resocialization of journalists writing in convergence editorials" (Singer, 2004). Mark Deuze (2004, 2005), revisited the "professional identity and ideology of journalists". Florence Le Cam (2005) studied the reconfigurations of identity at work among Quebec journalists struggling to redefine their identity in the digital age, with the advent of versatility, multimedia skills, a temporality of work accelerated and called into question the meaning of collective work. Cavelier Croissant (2002) exposes the dissociation, during the appropriation of the Internet by the press editors, between the economic concerns and the level of reflection on the renewal of the editorial model.

In France, many researchers study precisely the organizational transformations from the sociological or economic perspective (Charon, 2010; Charon \& Le Floch, 2011; Dupuy, 2013). Attias (2007) emphasizes the emergence of multi-media writing, often in logic of pooling costs. The reorganizations can range from the complete merger of newsrooms with redesigned rubrics to the recreation of editorial dedicated to mobile apps, with the aim of becoming editorials "web first", the paper edition coming after. Other works scrutinize managerial practices in newsrooms, recomposed to adapt to digital (Carbonnel \& Mercier, 2011; Charbonneaux \& Le Cam, 2012). Stéphane Cabrolié has meanwhile conducted a monograph of the site LeParisien.fr to study the "recomposition" of a digital copy (Cabrolié 2009, 2010), while Datchary has studied the "loosening of production formats" at Mediapart (Datchary, 2010). 
Many foreign works offer monographs or ethnographies of these organizational changes in editorials. For example, in his study about the identity of contemporary journalists, Le Cam seeks to identify some of the peculiarities that characterize online journalists and begin to establish an identity (Charbonneaux \& Le Cam, 2012, p. 62). On the other hand, the very notion of professionalism was debated in the light of developments in the journalistic profession (Aldridge \& Evetts, 2003) because "the progressive invention of integrated editorial teams accompanies a diversification, more important roles" (Degand \& Grevisse, 2012, p. 33). We can, therefore, witnessing a change in the journalistic paradigm (Brin et al., 2004) with dialectic between "destructuring and restructuring" (Demers, Charron, and de Bonville, 2007).

Schudson and Downie (2009) referring to "the reconstruction of American journalism". Sturgis (2012) dares to ask, "Are traditional media dead?", Continuing in the subtitle: "Can journalism survive in the digital world?" However, Allan points out the emergence of a true "ecology of online information", revealing "a climate where seemingly disparate initiatives can begin to consolidate into viable journalistic forms, practices, and epistemologies" (Allan, 2013, p. 154). Based on our discussion above, citizens now play an important role in the production of news, thus this new form of journalism has created new approaches in newsrooms, whatever it is labeled citizen journalism, participatory journalism, engagement, etc. (Melissa, 2017, p. 140).

Source selection. The publications of citizen journalists must also assimilate certain principles in order to be credible. It is not possible to impose the same constraints as professional journalists, but elements of regulation or self-regulation are essential. Natural self-regulation comes from the participatory nature of the web. When disseminated information is false, it generates comments that restore the truth or at least initiate debate. These comments help the reader more clearly perceive the goals of the writer. Internet users must also internalize some basic principles of the selection of information on the Internet. For example, we must first look for the author's qualification in relation to the subject treated. Other indicators can give details of the credibility, such as the number of links pointing to the concerned site. If the user sees through his other readings that the site is often cited in reference, it will receive more attention than if you never expect to talk about it.

\section{Conclusion}

\section{Citizen Journalists: New Filters for News}

First of all, this form of journalism cannot be considered professional journalism because they do not have the same objectives. A traditional journalist must put in perspective while respecting the maximum neutrality while the citizen can express himself freely by delivering his opinions. Readers submit to citizens' reflections on a voluntary basis and with full knowledge of the facts. On the contrary, the act of buying a newspaper, or the consumption of any other 
traditional media, implies the existence of a moral contract between the reader and the journalist.

Indeed, citizen journalism has seen its emergence thanks to the development of new technologies and the ease of publication of information on the internet. Yet this still requires some skills that are not yet available to all. This is why the articles on the Internet are mostly the work of people with computer skills. The citizen journalist like other bloggers, he writes to be read and be recognized by his peers. For this, he broadcasts his articles on participatory newspapers in order to benefit from a large audience. His work differs from that of the professional journalist. It is a form of press review with a thorough analysis and perspective, which will be the real added value of these articles. On the other hand, the citizen journalist writes outside the traditional media sphere, implying that he does not suffer the same pressures and can, therefore, afford to give a personal opinion. However, the reader of this new type of press must have the perpetually alert mind to avoid manipulation and always have mistrust vis-à-vis articles that cannot benefit from the credibility of a major newspaper or a known signature.

Despite the acceleration of information, journalistic competence remains necessary: cross-checking, verifying, synthesizing, analyzing information is a profession. The new channels cannot replace the journalist expertise. Moreover, despite the growth of citizen journalism, the audience of traditional newspaper sites is not weakening. This shows that citizen journalists are not "sources" of information but that they are new filters to the news.

\section{Self-Regulation "Real Added Value"}

Self-regulation refers to the coordination of societal interests according to a common purpose, which involves (at least potentially) importance for the common good (Collin 2016). This definition also presupposes that this coordination presents, at the institutional level, a certain degree of consolidation and sustainability. Self-regulation is not censorship or even self-censorship (Berleur \& Poullet, 2002). Self-regulation of citizen journalism aims to establish minimum principles of ethics, respect for human rights, values, the accuracy of the information provided, etc., while fully preserving the editorial freedom of the subjects and opinions expressed. There is no doubt that, Freedom of expression is certainly one of the founding tenets of the Internet, but we have to take into consideration that self-regulation would be the real added value or a compromise to keep the relation between professional and non-professional journalism.

\section{Citizen Journalism vs. Traditional Media: Vertical Relationship}

In the context of changes in traditional media and journalism (technological and moral), citizen journalism is a phenomenon that they cannot ignore. Francophone websites believe that it can offer an alternative to traditional journalism. However, AgoraVox considers desirable collaboration between the two types of journalism, what he puts forward in his model of investigative journalism mixing know-how and supervision of the professionals with the 
strength of the number of the amateurs. Although some professional journalists criticize citizen journalism, it is nevertheless important to note that both types of journalism have a collaborative relationship that can be described as vertical. Their relationship can be referred to as vertical because the information starts from the bottom, that is to say, that the information goes from the citizen journalist to the professional journalists even if they depend on the first ones to enrich their stories like this. For example, the bombing that took place at the Boston Marathon in 2013. The professional journalists heavily based their information on the stories of people who are not journalists and who were on the scene and who published stories about their Twitter and or Facebook accounts. It was people who were contacted by the continuous news channels playing for the occasion the role of a correspondent at the disaster scene. Another example of their collaboration is found in the creation of TV and radio programs, websites, blogs, Facebook accounts, Twitter accounts and YouTube by the mainstream media to allow people from around the world to contribute photos and videos of news last hour. In this respect, the traditional media like CNN, BBC, and France 24, respectively created I-Report, Your News, to gather information from the public. This highlights the importance of collaboration between professional journalism and citizen journalism.

\section{Professional Standards and Code of Ethics}

Despite the existing collaboration between traditional journalism and citizen journalism, the latter is a threat to the profession. Journalism, like all others, is subject to professional standards and code of ethics and is governed by laws. Anyone aspiring to practice it must undergo training, but this is, unfortunately, not often the case for journalists of citizen journalism. Just as it takes years of training and practice to become a doctor, it is just as much as it takes years of training to become a journalist. Being able to make good pictures, a beautiful video and know how to tell the story does not make someone a journalist but an eyewitness who tells a fact. The journalist is one who respects the rules and laws of the profession even when taking photos that involve the rule of privacy of the subjects of the story. Besides, by treating subjects, the professional journalist respects certain elements like the private life and the anonymity of the subject, which would not respect necessarily from the citizen journalist, and this tarnishes the image of journalism and puts the profession to bad use. In sum, we can say that citizen journalism involves the active participation of citizens in the collection of news and reporting events. On the other hand, it is necessary to emphasize its importance. Citizen journalism plays the multiple roles of denouncing corruption, encouraging accountability, documenting abuse of power while offering alternative views of local and international news. However, its collaboration with traditional journalism is an added value, because it alone is not credible. 


\section{References}

Aldridge, M., \& Evetts J. (2003). Rethinking the Concept of Professionalism: The Case of Journalism. British Journal of Sociology, 54(4), 547-564.

Allan, S. (2007). Citizen Journalism and the Rise of "Mass Self-communication": Reporting the London Bombings. Global Media Journal, Australian Edition, 1(1), 120.

Allan, S. (2013). The Emerging Ecology of Online News. In F. Lee, L. Leung, J. Qiu, D. Chu (Ed.), Frontiers in new media research (pp. 153-172). New York: Routledge.

Ananny, M., \& Kreiss, D. (2011). A New Contract for the Press: Copyright, Public Domain Journalism, and Self-Governance in a Digital Age. Critical Studies in Media Communication, 28(4), 314-333.

Attias, D. (2007). L'impact d'Internet sur l'économie de la Presse: Quel Chemin vers la profitabilité? (Internet Impact on Press Economics: Which Path to Profitability?). $\mathrm{PhD}$ Thesis in Economics, University of Paris, France.

Aubert, A. (2011). Le participatif perçu par les professionnels du journalisme: état des lieux (The participative perceived by the professionals of the journalism: state of the places). Les Cahiers du Journalisme, 22/23, 42-55.

Berleur, J., \& Poullet, Y. (2002). Réguler Internet (Regulate the Internet). Études, 11(397), 463- 75.

Bowman, S., \& Willis, C. (2003). We Media: How Audiences ashapinging the Future of News and Information. A Seminal Report. Reston: The Media Centre at the American Press Institute. Retrieved from goo.gl/WSjaZc. [Accessed: $5^{\text {th }}$ April 2017]

Braun, J., \& Gillespie, T. (2011). Hosting the Public Discourse, Hosting the Public. Journalism Practice, 5(4), 383-398.

Brin, C., Charron, J., de Bonville, J. (2004). Nature et transformation du journalisme (Nature and transformation of journalism). Québec: Presses de l'Université Laval.

Cabrolié, S. (2009). La recomposition d'une organisation de presse: le cas du Parisien.fr (The recomposition of a press organization: the case of Parisien.fr). Terrain et travaux, 15(1), 127-145.

Cabrolié, S. (2010). Les journalistes du Parisien.fr et le dispositif technique de production de l'information (The journalists of Parisien.fr and the technical device of production of the information). Réseaux, 160-161, 79-100.

Carbonnel, A., \& Mercier, A. (2011). Web-journaliste: une identité fragile dans un contexte de mutations professionnelles (Web-journalist: a fragile identity in a context of professional changes). 22nd Congress of the AGRH. Retrieved from http://www. academia.edu/1983234. [Accessed: $4^{\text {th }}$ February 2017]

Cardon, D., \& Delaunay-Teterel, H. (2006). La production de soi comme technique relationnelle (Self-production as a relational technique). Réseaux, 138, 15-72.

Carr, D. J., Barnidge, M., Byung, G. L., \& Tsang, S. J. (2014). Cynics and Skeptics: Evaluating the Credibility of Mainstream and Citizen Journalism. Journalism \& Mass Communication Quarterly, 91(3), 452-470.

Cavelier Croissant, V. (2002). La presse quotidienne française sur Internet. Stratégies discours et représentations des acteurs français de presse quotidienne d'information générale dans le cadre du développement de leur site Internet (The French daily press on the Internet. Strategies speeches and representations of the French actors of daily newspaper of general information within the framework of the development of their Internet site). Thesis, Information and Communication Sciences, Stendhal University Grenoble, France. 
Charbonneaux, J., \& Le Cam F. (2012). Pratiques managériales et socialisation des journalistes en ligne (Managerial practices and socialization of journalists online). In G. D. Nguyen, \& P. Créach (Ed.), Le numérique en sociétés (Digital business), pp. 131-156. Paris: L'Harmattan.

Charon, J. M., \& Le Floch, P. (2011). La Presse en ligne (Online Press). Paris, La Découverte.

Charon, J. M. (2010). De la presse imprimée à la presse numérique. Le débat français (From the printed press to the digital press. The French debate). Réseaux, 160-161, 255-281.

Cheynel, N., \& Noblet, A. (2009). La mobilisation du mythe du journaliste-reporter sur le web, nouvel Eldorado participatif? (The mobilization of the myth of journalistreporter on the web, new participative Eldorado?). Retrieved from https://bit.ly/2Fql Zxe.[Accessed: 16th March 2017].

Collin, P. (2016). Autorégulation sociétale et autorégulation régulée - des catégories fécondes pour une analyse (juridico-) historique? (Societal self-regulation and regulated self-regulation - fertile categories for (juridico-) historical analysis?). Trivium, 21. Retrieved from https://bit.ly/2SXQSfx. [Accessed: 22th June 2018]

Datchary, C. (2010). Ce que le Web 2.0 fait à l'autonomie journalistique. L'expérience Médiapart (What Web 2.0 does to journalistic autonomy. The Médiapart experience). In C. Lemieux (Ed.), La subjectivité journalistique (Journalistic subjectivity), pp. 123-142. Editions de l'EHESS.

De Rosnay, J. (2005). Des mass média aux média des masses dans Agora Vox (From the mass media to the media of the masses in Agora Vox). Retrieved from https://bit.ly/2STqLGy. [Accessed: 22th October 2017]

De Rosnay, J., \& Carlo, R. (2006). La révolte du pronetariat - Des mass média aux média des masses (The revolt of the pronetariat - From the mass media to the media of the masses). Editions Fayard.

Deborah S. C. (2008). Interactive Features of Online Newspapers: Identifying Patterns and Predicting Use of Engaged Readers. Journal of Computer-Mediated Communication, $3,658-679$.

Degand, A., \& Grevisse, B. (2012). Journalisme en ligne, pratiques et recherches (Online journalism, practices and research). Bruxelles: de Boeck.

Demers, F. (2007). Déstructuration et restructuration du journalisme (Deconstruction and restructuring of journalism). Tic \& Société, l(1). Retrieved from https://bit.ly/2H8E 309. [Accessed: 4th March 2017]

Deuze, M. (2004). What is Multimedia Journalism. Journalism Studies, 5(2), 139-152.

Deuze, M. (2005). What is journalism? Professional identity and ideology of journalists reconsidered. Journalism Theory Practice \& Criticism, 6(4), 443-465.

Deuze, M. (2008). The changing context of news work: liquid journalism and monitorial citizenship. International Journal of Communication, 2(5), 848-865.

Deuze, M., Bruns, A., \& Neuberger, C. (2007). Preparing for an age of participatory news. Journalism Practice, 1(3), 322-338.

Dupuy, C. (2013). Les Travailleurs du web: innovations et catégories professionnelles dans la presse en ligne (Web Workers: innovations and professional categories in the online press). Revue de l'IRES, 77, 107-127.

Estienne, Y. (2007). Le journalisme après Internet (Journalism after the Internet). Paris: L'Harmattan.

Fico, F., Lacy, S., Wildman, S., Baldwin, T., Bergan, D., Zube, P. (2013).Citizen Journalism Sites as Information Substitutes and Complements for United States Newspaper Coverage of Local Governments. Digital Journalism, 1(1), 152-168. 
Fielder, T. (2009). Crisis Alert: Barack Obama meets a Citizen Journalist. In S. Allan, \& E. Thorsen (Ed.), Citizen Journalism - Global Perspectives, pp. 209-221. New York: Peter Lang Publishing.

Flichy, P. (2001). L'imaginaire d'internet (The imagination of the internet). Paris: La Découverte.

Gillmor, D. (2004). We the Media: Grassroots Journalism by the People, for the People. Sebastopol: O'Reilly Media.

Goode, L. (2009). Social News, Citizen Journalism, and Democracy. New Media \& Society, 11(8), 1287-1305.

Lasica D. (2003). What is participatory journalism? Online Journalism Review. Retrieved from https://bit.ly/2e007IO. [Accessed: 22th June 2018]

Larsson, S. (2014). Battling Mainstream Media, Commentators and Organized Debaters: Experiences from Citizens' Online Opinion Writing in Sweden. Nordicom Review, $35(2), 77-89$.

Le Cam, F. (2005). L'identité du groupe des journalistes du Québec au défi d'Internet (The identity of the group of Quebec journalists to the challenge of the Internet). $\mathrm{PhD}$ Thesis. Laval University and the University of Rennes, France.

Le Cam, F. (2006). États-Unis: les weblogs d'actualité ravivent la question de l'identité journalistique (United States: news weblogs revive the issue of journalistic identity). Réseaux, 138. Retrieved from https://bit.ly/2AN7Vdr. [Accessed: $4^{\text {th }}$ March 2017]

Le Cam, F. (2012). Une identité transnationale des journalistes en ligne? (A transnational identity of online journalists?). In A. Degand, B. Grevisse (Ed.), Journalisme en ligne, pratiques et recherches (Online journalism, practices and research), pp. 61-85. Bruxelles: de Boeck.

Melissa, W. (2017). Mapping Citizen and Participatory Journalism. Retrieved from https://bit.ly/2FBbXbL. [Accessed: $4^{\text {th }}$ June 2017]

Mondoux, A. (2011). Histoire sociale des technologies numériques de 1945 à nos jours (Social History of Digital Technologies from 1945 to the present day). Québec: Éditions Nota bene.

Neveu, É. (2009). Sociologie du journalism (Sociology of journalism). Paris: La Découverte.

Newman, N. (2012). Social Media in the Changing Ecology of News. Retrieved from https://bit.ly/1FmAafU. [Accessed: 17 ${ }^{\text {th }}$ June 2017].

Nobre-Correia, J. M. (2006). Journalisme: une certaine mort annoncée (Journalism: a certain death announced). Communication et langages, 147, 15-24.

Olivier, T. (2007). Le journalisme citoyen en ligne: un public réifié? (Online Citizen Journalism: A Reified Audience?). La Revue Hermès, 1(47), 115-122.

Peters, C., \& Broersma, M. (2013). Rethinking journalism: trust and participation in a transformed news landscape. New York: Routledge.

Pignard, N., \& Noblet, A. (2008). L'encadrement des contributions "amateurs" au sein des sites d'information: entre impératif participatif et exigences journalistiques (Supervision of "amateur" contributions within information sites: between participatory imperative and journalistic requirements). @SIC. Retrieved from https://bit.ly/2FxTcWV. [Accessed: 17th February 2018]

Pledel, I. (2006). Les blogs, les promesses d'un média à travers ses représentations collectives: illusions ou réalités à portée de clic? (Blogs, the promises of a media through its collective representations: illusions or realities at your fingertips?). Les cahiers du journalism, 16.

Rabia, N. (2017). Citizen Journalism vs. Mainstream Journalism: A Study on Challenges Posed. Athens Journal of Mass Media and Communication, 3(1), 55-76. 
Radsch, C. (2013). The Revolutions will be Blogged: Cyberactivism and the $4^{\text {th }}$ Estate in Egypt. Doctoral Dissertation, American University.

Rebillard, F. (2007). Le web 2.0 en Perspective: Une Analyse Socio-économique de l'Internet (The Web 2.0 in Perspective: A Socio-Economic Analysis of the Internet). Paris: L'harmattan.

Rebillard, F. (2008). Le journalisme participatif, un maillon dans la chaîne numérique de l'information d'actualité (Participatory journalism, a link in the digital news channel). In PROULX, Serge et Florence MILLERAND. Web social: mutation de la communication, pp. 15-30. Québec: Presses de l'Université du Québec.

Rosen, J. (2001). What are Journalists for?. New York: Yale University Press.

Ruellan, D. S. (2007). Penser le journalisme citoyen (Thinking citizen journalism). In Marsouin.org. Retrieved from https://bit.ly/2RwrYH6. [Accessed: 25th February 2018]

Schudson, M., \& Downie, L. (2009). The Reconstruction of American Journalism. Columbia Journalism Review. Retrieved from https://bit.ly/2Mcv90Z. [Accessed: 25th August 2017]

Singer, J. (2003). Who are these Guys? The Online Challenge to the Notion of Journalistic Professionalism. Journalism, 4(2), 139-163.

Singer, J. (2004). More than Ink-strained Wretches: The Resocialization of Print Journalists in the Converged Newsroom. Journalism \& Mass Communication Quarterly, 81(4), 838-856.

Sturgis, I. (2012). Are Traditional Media dead? Can Journalism Survive in the Digital World? New York: Idebate Press.

Tétu J. (2008). Du public journalisme au journalisme citoyen (From public journalism to citizen journalism). Questions de communication, 13, 71-88.

Tredan, O. (2007). Le «journalisme citoyen» en ligne: un public réifié? (Citizen journalism online: a reified audience?). La Revue Hermès, 47, 115-122.

Ward, Steven J. A. (2011). Ethics and the Media - An Introduction. Cambridge: Cambridge University Press. 
